\title{
Education for Sustainable Development: A Critical Analyses
}

\author{
Abeer Mohamed Ali Abd Elkhalek ${ }^{1}$ \\ ${ }^{1}$ College of Management \& Technology, Arab Academy for Science, Technology and Maritime Transport, Egypt \\ Correspondence: Abeer Mohamed Ali Abd Elkhalek, Associate Professor of Economics, College of Management \\ \& Technology, Arab Academy for Science, Technology and Maritime Transport, Egypt. E-mail: \\ abeer_abdelkhalek@yahoo.com
}

Received: April 22, 2021

Accepted: May 28, 2021

Online Published: May 31, 2021

doi:10.5539/ijef.v13n6p181

URL: https://doi.org/10.5539/ijef.v13n6p181

\begin{abstract}
Education has a key role in attaining sustainable development goals for both of developing and developed countries. Considering "the Decade of Education for Sustainable Development" approved by United Nations, the gap between the real and the intended contribution of education to sustainable development must be assessed. The main aim of the current study is to evaluate the contribution of education to sustainable development and explore efficient mechanisms to maximize that contribution regarding the main pillars of sustainable development. This paper goes beyond a study concentrating exclusively on the role of education in achieving sustainable development goals as it also examines the relation between education and each dimension of sustainable development to conclude related policy recommendations which are exposed to be useful in that regard.
\end{abstract}

Keywords: sustainable development, sustainable development goals, decade of education for sustainable development

\section{Introduction}

Sustainable development is the process of satisfying the requirements of the current generation without compromising the future generations' ability to satisfy their own requirements (Brundtland, 1987). So, countries must join efforts to strike a balance between improving the quality of human life and protecting the environment for the sake of future generations. All countries face challenges in gathering social and environmental concerns in economic development to enhance sustainability. A main challenge here is the preparation of citizens empowered with the knowledge, skills, values and attitudes to realise sustainable development which may be done through introducing the principles of sustainability in all aspects of the formal and non-formal education institutions. Within that context, education is a key factor in countries' development as it is proven to be effective in fighting poverty, creating more opportunities for labour market participation, increasing economic growth rate, allocating resources within the common environmental contests and ultimately, achieving sustainable socio-economic development. The most substantial step on the way to sustainable development was the publication of an international report titled "Our Common Future" by World Commission on Environment (WCED) in 1987. The report defined sustainable development as "Development that meets the needs of the present without compromising the ability of future generations to meet their own needs". It highlighted the idea of relative scarcity of resources and the process of allocating resources which may force the present generation to compromise his ability to meet the critical wants in order to assure the ability of the future generations to fulfil their developmental needs. As a result, all countries aim at adopting sustainable development goals in the context of national policy and international cooperation (Brundtland, 1987). The previously mentioned conference of united states focused on the role of education in achieving developmental goals related to the natural environment protection and it stated the period from the year 2005 to 2014 as the "Decade of Education for Sustainable Development (DESD)" indicating that education is a central component for attaining sustainable development (UNESCO, 2006).

\section{Literature Review}

Sustainable development is a key principle related to human development as a core target (Keiner, 2005). Sustainable development as a concept was articulated in "Our Common Future", the major outcome document of the 1987 World Commission on Environment and Development (WCED), as development which "meets the 
needs of the present without compromising the ability of future generations to meet their own needse (Brundtland Report, 1987).

The first principal of the Rio Declaration on Environment and Development stated that "Human beings are at the centre of concerns for sustainable development. They are enabled to a well and productive life as the developmental and environmental requirements should be considered as fundamental components of the process of development. Economic and social development is strongly connected to environmental quality in a complicated process called in economic research as "sustainable development". To achieve sustainable development, environmental considerations must be integrated as a main part of the development process and cannot be considered in isolation from it (UN 1992). John Foster (2002) proved that sustainable development is a process of improving the human being performance through education. The idea behind that can be summarised in the context that education help persons to make rational daily choices in their own life which- in turn- have positive reflections on the collective behaviour in the society (Gough \& Scott, 2007).

The causal connection between economic development and education represented a main focus of many econometric analyses. It was considered that the improvement of human well being, specifically in the last two centuries, is largely due to education (Stevens \& Weale, 2004), and economic development is directly influenced by both qualitative and quantitative elements of education levels (Schlattmann, 2010).

\section{Methodology of the Study}

To achieve the main objective of this study, the methodology used is descriptive in nature because it mostly explores the relation between education and every dimension of sustainable development (economic, social, and environmental dimensions) at two levels of analysis:

1) Analyses of the relation between education and sustainable development in light of the last studies in the field of research which proved how education is connected with the different dimensions of sustainable development.

2) Using applied study to explore the proven relation between education and sustainable development considering countries' experiences with more focus on the countries which succeeded in orienting education policies toward achieving sustainable development goals.

The empirical study depends on a combination of inductive and deductive approach to draw a complete picture about how can policy makers improve educational strategies to contribute effectively to the process of sustainable development.

\section{Analysis and Discussion}

\subsection{The Role of Education and Dimensions of Sustainable Development}

As was shown earlier in this study, sustainable development requires making a balance between economics concerns, social welfare, and environmental domains in the context of insuring justice in distributing resources between the present and futural generations to prevent the exhaustion of the resources required for the continuation of life on planet (Mahruf et al., 2011). Considering that human beings are at the centre of concern for sustainable development (UN, 1992: Principle 1), education contributes to sustainable development by developing human potential as well as social growth (Dewey, 1899). Education represents a main human right and an essential part of access to political participation and contribution of men and women in the labour force and economic development (Haq, 1997; Torres, 1990). So, education helps in preparing persons for social competences and should be contributing to the competence of people to participate in and construct a sustainable way of life (JESD, 2011). A complete set of sustainable development goals were finally approved in September 2015 and it became unavoidable to look precisely at each goal and identify how education can play an effective role in achieving sustainable developmental goals. The increasing stress on the wider view of development rather than the limited view focusing only on the economic view of development due to exploring the three pillars or dimensions of sustainable development: economic pillar, social pillar, and environmental pillar. That new approach due to the acknowledgement that not only policy interventions or technical tools are required, but also behavioural change is serious to achieve sustainable development. But the proposed SDGs apply to the world, thus the role of education in its widest sense, which include training, creating public awareness, scientific research, and sharing information, becomes a significant strategy for enhancing sustainable development (UNESCO, 2016).

\subsubsection{Education and the Economic Dimension of Sustainable Development}

In their empirical analyses, Afzalet et al. (2012) examined the impacts of education level on economic 
development and demonstrated that economic development requires more investing in education process as a multidimensional process. The main point of view here that education alleviate poverty through increasing workers' productivity, and it was proven that there a significant relation between poverty and education, and between education and sustainable development as educated people have higher earning potential and are expected to get good job opportunities and earn more incomes which help them to improve their life standards. So, many literatures argued that education may be viewed as the first step to achieve sustainable development process. Education has an important role in the increasing people's abilities and maintain sustainable development. Expanded the importance of educated labours in addressing new technological means of production had an important role in improving economic performance, specifically in developing economies like Pakistan which face a lake of physical and human resources (HDR, 2001; Adawo, 2011).

Wolff and Gittleman (1993), examined the relation between higher education and productivity and concluded that there is a significant positive relation between the level of education measured by enrolment percentage and productivity measured by growth rate of worker productivity. Concerning education in definite careers such as science and technology education, the analyses showed that a positive relation between the annual number graduates of scientists and engineers and economic development. To examine that conclusion, Bloom, Hartley, and Rosovsky (2006) evaluated the financial revenues produced through tax and paid by persons and they estimated positive effects of research and innovation in universities on economic performance in developed countries only, but the study did not examine the relation between the two mentioned variables in developing or less developed countries. In the same context, Abbas and Peck (2007) succeeded to estimate the relation between investing in human resources and economic development. They employed time series data for Pakistan during the period (1960-2003) using OLS technique and concluded that human capital responsible about no less than 40\% out of the total increase in gross domestic product. So, the researchers proved that low investment in education results in most of cases in decrease in economic growth rate. Therefore, it was proved that increasing the educational level of the individuals results in decreasing the number and percentage of poor individuals as education has a significant impact on knowledge and skills which help individuals to access to higher wages jobs (Tilak, 1994).

In low- income economies, the social revenues of primary education exceed the social returns of higher education and thin, it may be concluded that Millennium Development Goals could not be achieved by only universalising primary education. Additionally, Njong (2010) concluded that the delivery of primary education without considering secondary and higher education constrains sustainable development because of the resulting deficiency of skills in managerial work and in administration. The analyses also indicated linear relation between education and incomes as education increases the opportunity of being hired in high wages organizations and earn much more than less-educated workers as higher levels of education due to earning more incomes, decreasing unemployment rates, and increasing labour force contributions to economic activities. Many resent studies have explored the relationship between education level and expected earnings and concluded that wages rates are supposed to be higher as a result of having more years of schooling regarding that the high education level reflects higher labour productivity. As economic development is important for reducing poverty, education Also creates productivity improvements that improve and support sustainable development. It was proved that increasing educational level by one additional year results in $2.5 \%$ increase in the annual growth in per capita income. On the other hand, it was identified that variances in primary education help in explaining many variances in economic growth rates between countries as the variances in primary education explains more than $50 \%$ of the variance in productivity growth rates which influencing economic development directly and indirectly (Riddell, 2006). Another study also showed that the quality of education affects productivity through affecting the knowledge and skills attained by labour force. The well- educated workers create non-monetary returns and economic outcomes that cannot be interpreted in the form of higher earnings (Temple, 2002).

\subsubsection{Education and Social Dimension of Sustainable Development}

In general, there is a need to educate people to have a sustainable mind-set. Within that contest, and according to Gough and Scott (2007), scientific research afford evidence for what essential knowledge is needed to have sustainable development. The educational institutions should be part of the social transformation process to developmental societies. Education can empower women to overcome forms of gender discrimination, so they can make more informed choices about their lives. In many countries, education represent an important factor in achieving sustainable development as about 70\% of the fertility decline in Brazil during the period (1960-1980) was explained by enhancements in education. Also, females with law education in sub-Saharan Africa have 7 births-on average- compared with 6 births for those with primary education, and 4 for women with secondary 
education. Research estimated that if all females had secondary education, births would fall by $37 \%$. With respect to justice in income distribution as a social aspect of sustainable development, the disparities and Inequalities increases as a result of economic growth and industrial sector developments as the development process includes increasing movement of more workers from the agricultural sector which pays higher wages to other sectors with relatively low wages. In that regard, income disparities continue its increasing until the workers complete the shifting process from agricultural sectors to the other sectors of the economy. Education has an important role here as it enables the structural change of the economy and motivates well educated workers to move between sectors and it can at the same time eliminates income disparities when educational opportunities are distributing equitably either between different persons and different regions within each country or between different countries. Recent research indicated that increasing post primary education opportunities helps in preventing disparity from increasing. Additionally, education affecting human behaviour as persons with more education usually have adequate awareness about the environmental concerns and tend to support public policies related to environmental protection (Robert et al., 2016).

\subsubsection{Education and the Environmental Dimension of Sustainable Development}

While more developed countries are supposed to use most of their available resources in producing excess goods and services for exports, less developed countries use the available resources to produce increasing amount of food which are required to fulfil the increasing requirements of their growing population, specially with the heigh poverty rates. This race of resources exploitation has created a dangerous situation all over the world and has made the lives of people and animals in danger. It is more than proven that judicious use of environmental resources is a vital need for sustainable economic development. There is a strong relation between environment and sustainable development. Environmental pollution is great challenge for most countries and natural resources are exhausting quickly, creating scarcity problem for the next generation which means that increasing number of populations are suffering seriously as every country is trying to increase economic growth to alleviate living standard of their people and on the other hand while environmental problems are becoming complicated due to excessive use of resources. Then, there is a global need to consider environmental considerations in their policy making. Most countries, of the Asian and European region have evolved complex and erudite procedures to do that, but the environmental degradation is still accelerating across many different environmental dimensions in many parts of the world (Ekins, 2003). Sivapalan (2016), concluded that developing people who can live and behave in sustainable patterns of consumption and production contexts is critical to enable individuals to do that by providing them the information, abilities, principles, personalities and skills required to do so. Leaders' world over has agreed that it takes education to develop these knowledge, skills, values and characters required for sustainable development. So, education has an important and vital role in achieving the sustainable development goals. UNESCO (2005) explained that education represent a major factor in achieving the development goals as education enables people to build their knowledge, skills and attributes to work and live in a way that maintains environmental, societal and economic well-being, both for present and future generations. According to the UN Conference on the Human Environment in Stockholm (1972), development of the environment for present and future generations is an important feature of individuals' and governments' responsibility. Underdevelopment of developing countries and industrialisation and technological development of the industrialised countries were seen as the reasons for the environmental problems. The correlation between education and sustainable use of natural resources is significant as education have substantial impacts on the way individuals decide to choose in using of these resources, mainly in areas of resource scarcity. For instances, educated farmers in China had more tendency to use rainwater and additional irrigation technology to alleviate water deficiencies and educated households are supposed to use various techniques of water cleansing. Recent research of households in ten OECD countries indicated that persons with more education tend to use water more rationally which refer to the vital role of education can have an impact on in directing behaviour toward sustainable use of natural resources, specifically in zones of resource scarcity. On another hand, education helps citizens adapt to the environmental concerns such as climate change. The necessity for change is urgent for many inhabitants faced with increasing temperatures, rising sea levels and more common extreme climate occurrences. Change is mainly important for poorer nations, where the capability of governments to act is relatively limited. A survey of farmers in some African countries concluded that persons with more education were more expected to make at least one adaptation as it was estimated that a year of education reduce the probability of no adaptation by $1.6 \%$ (O'Flaherty \& Liddy, 2018).

\subsection{Education and SD Considering Countries' Experiences}

Policy makers in both developed and developing countries seeks to answer a main question: How can education play a role in promoting sustainable development? To answer this question, one of the following three points of 
views is used: education about sustainable development, education for sustainable development and education towards sustainable development. In summary, education helps on developing the main skills that are essential to build more sustainable economic development which means that education systems' improvements and high-quality programs' designing can make a serious difference to production patterns and social and economic inequality. The 2002 Johannesburg World Summit on Sustainable Development (WSSD) suggested that sustainable development concepts, actions and principles should be integrated into all levels of education, in order to promote education as a key agent for change (United Nations, 2002). Now, the role of education in achieving sustainable development goals will be shown depending on some case studies.

For example, In the Case of India we can state that Indian experience illustrates the important role of education achievement of all sustainable development goals. Indian policy makers built a comprehensive strategy depending on many educational programs focus on providing continuing support to individuals who are already vulnerable, during their transformational stage. In that strategy, "Education for Sustainable Development" seeks to resolve problems through democratic engagement where skills and resources are joint, and people learn from each other (Karthikeya, 2016). Another example is The Case of Costa Rica which proves that sustainable development policies including education for sustainable development strategy help to strengthen and drive changes in education systems (Robert, 2016).

\subsection{The Real Contribution of Education to Sustainable Development}

As was stated in the current study, education system and educational institutions have a great role to play in achieving sustainable development with its various pillars. The serious question now is: Regarding the current efforts all over the world to achieve the sustainable development goals, how the real contribution of education to sustainable development would be evaluated? The answer on that question is so confusing considering the scarcity of empirical research which assessing the exact returns of education in the context of contemporary developmental goals. The very limited empirical evidence represents a key challenge for policy makers to evaluate the outcomes of educational programs in the context of implementing the principle of "Education for Sustainable Development" in educational institutions and inside colleges' and schools' classrooms. Moreover, large scaled behavioural studies are needed urgently to assess the real impacts of educational domains not only on students' knowledge and skills, but also -and more important- on their attitudes and behaviours related to the targeted developmental goals.

Evaluating the real effects of specific educational programs on economic, social, and environmental concerns could be enhanced through analysing the students' attitudes and behaviours before and after the application of that program in the education's institutions. If the outcome of educational programs improved the knowledge of the students without adapting their attitudes and behaviour towards sustainable development goals, the outcome of those programs will be so limited in making a succeed social transformation targeting the developmental process' objectives. Then, 'Education for sustainable development' programs must Focus mainly on its outcomes and impacts on behaviours not only on the executive and administrative procedures. For most of developing countries, educational programs are designed regardless the capabilities and willingness of existing educational infrastructure to implement which due to restricting the role of education in making the targeted outcomes. Education can make a difference if high quality educational programs succeeded in motivating behavioural change toward more sustainable economic and social practises. On the other hand, Educators and teachers need to be trained on managing the behavioural change process and more quantitative and qualitative indicators are needed for the evaluation procedures. Finally, institutional environment must be prepared, and the resources' availability must be insured to support the social transition toward a new platform depends on rethinking education as a systemic tool for transformative social change.

\section{Conclusion \& Policy Recommendations}

Our findings showed that there is a significant and crucial role of education in achieving sustainable development. Education should provide students with the skills, perspectives, values, and knowledge to live sustainably in their communities. It should be interdisciplinary, integrating concepts and analytical tools from a variety of disciplines (UNESCO, 2002). These results clearly give the message to the developing countries there is a high contribution of education to sustainable socio-economic development as it develops the knowledge, skills, values and world views necessary for people to act in ways that contribute to more sustainable patterns of living and enables individuals and communities to reflect on ways of interpreting and engaging with the world. Education has a fundamental role to play for providing the new generation with a vision of education that seeks to empower them to assume responsibility for creating a sustainable future (Kanbar, 2012). Based on the research results, this paper makes the following policy recommendations: 
1) Achieving sustainable development requires a profound transformation of how individuals think and act. To create a more sustainable world and to engage with sustainability-related issues as described in the SDGs, individuals must become sustainability change-makers. They require the knowledge, skills, values and attitudes that empower them to contribute to sustainable development.

2) Developing countries governments should put education in high priority in education, especially in the public sector considering that education which promotes economic growth alone may lead to an increase in unsustainable consumption and production patterns.

3) Integrating the principle of education for sustainable development in all learning settings to ensure the process of reorienting education policies towards sustainable development will succeed.

\section{Limitations \& Direction for Future Studies}

To successfully activate the contribution of education to sustainable development, more future studies are needed to design an integrated strategy for the goal to be reached with more focusing on the role of each element of the society: government, private sector, civil society and every human being across the country. Further studies are also needed to innovate new qualitative and quantitate indicators to evaluate the outcomes of the designed and implemented educational programs as a key step to explore effective mechanisms for maximizing the positive impacts of education on each dimension of sustainable development.

\section{References}

Abu, P. B., \& Jonathan, E. O. (2010). Higher Education Research and the Economies of Scale of Sustainable Development in Africa. European Journal of Scientific Research, 45(1).

Adawo, M. A. (2011). Has Education Contributed to the Economic Growth of Nigeria? Journal of Economics and International Finance, 1(3).

Adiqa, K. (2011). Role of University Education in Poverty Alleviation in Pakistan. Interdisciplinary, Journal of Research in Business, (7).

Afzal, M., Malik, M. E., Begum, I., Sarwar, K., \& Fatima, H. (2012). Relationship among Education, Poverty and Economic Growth in Pakistan: An Econometric Analysis. Journal of Elementary Education, 22(2).

Brundtland, G. (1987). Our Common Future: Report of the 1987. World Commission on Environment and Development, United Nations.

Camelia, B., \& Vasile, B. (2013). Education's Contribution to Sustainable Economic Growth in Romania. Journal of Social and Behavioural Sciences, 81. https://doi.org/10.1016/j.sbspro.2013.06.403

Cheung, Y. K. A. (1997). The Concept of Sustainable Development: An Environmental Assessment Approach for Hong Kong and the Pearl River Delta; Principles and Practices. PhD Thesis, The University of Hong Kong.

Craig, R.W. (2006). The Impact of Education on Economic and Social Outcomes: An Overview of Recent Advances in Economics. University of British Columbia.

Ekins, P. (2003), Identifying Critical Natural Capital. Ecological Economics, 44(2). https://doi.org/10.1016/S0921-8009(02)00278-1

Fien, J., \& Maclean, R. (2000). Teacher Education for Sustainability, Two Teacher Education Projects from Asia and the Pacific. Journal of Science Education and Technology, 9(1). https://doi.org/10.1023/A:1009420923692

Fien, J., \& Wilson, D. (2005), Promoting Sustainable Development:The Bonn Declaration. Orientating Tvet for Sustainable Development, 35(3). https://doi.org/10.1007/s11125-005-4265-1

Fien, J., Maclean, R., \& Park, M. G. (2008). Work, Learning and Sustainable Development: Opportunities and Challenges (Vol. 8). Springer Science \& Business. https://doi.org/10.1007/978-1-4020-8194-1

Foreman-Peck, J., Qaisar, A., \& James, F. (2007). The Mincer Human Capital Model in Pakistan: Implications for Education Policy. Cardiff Economics Working Paper No. 24.

Gerd, M., \& Peter, J. W. (2017). Education for Sustainable Development: Reflections from the UNESCO Chairs Program.

Gough, S., \& Scott, W. (2007). Higher Education and Sustainable Development: Paradox and Possibility. New York: Routledge. https://doi.org/10.4324/9780203938423 
Hawkes, D., \& Ugur, M. (2012). Evidence on the Relationship Between Education, Skills and Economic growth in low-income countries: A systematic Review. London: EPPI-Centre, Social Science Research Unit, Institute of Education, University of London.

Hofman, M. (2015). What is an Education for Sustainable Development Supposed to Achieve: A Question of What, How and Why. Journal of Education for Sustainable Development, 9(2). https://doi.org/10.1177/0973408215588255

Hofmann, C., \& Strietska-Ilina, O. (2013). Skills for Green Jobs: Gearing up Education and Training for Green Growth. Paris: Organization for Economic Cooperation and Development (OECD).

Johnston, A. (2007). Higher Education for Sustainable Development, Final Report of International Action Research Project. Based on Research Carried out by Andy Johnston, Seconded to the OECD from Forum for the Future, October 2006 - March 2007.

Kartikeya, V. S. (2016). Education as a Key Driver for Sustainable Development Goals: Case Studies from India. Global Education Monitoring Report, UNESCO 2016.

Leal, F. W. (2010). Teaching Sustainable Development at University Level: Current Trends and Future Needs. Journal of Baltic Sea Education, 9(4).

Mahruf, M., Shohel1, C., \& Andrew, J. H. (2011). Models of Education for Sustainable Development and Nonformula Education: A Bangladeshi Perspective. Journal of Education for Sustainable Development, $5(1)$.

Mankiw, N. G., Romer, D., \& Weil, D. N. (1992). A contribution to the Empirics of Economic Growth. Quarterly Journal of Economics, 107. https://doi.org/10.2307/2118477

Mochizuki, Y., \& Fadeeva, Z. (2010). Competences for Sustainable Development and Sustainability. International Journal of Sustainability in Higher Education, 11(4). https://doi.org/10.1108/14676371011077603

Njong, A. M. (2010). The effects of Educational Attainment on Poverty Education in Cameroon. Journal of Education Administration and Policy Studies, 2(1).

O'Flaherty, J., \& Liddy, M. (2018). The Impact of Development Education and Education for Sustainable Development Interventions: A Synthesis of the Research. Environmental Education Research, 24(7). https://doi.org/10.1080/13504622.2017.1392484

Pankaj, K. P., \& Chitralekha, M. (2016). Impacts of Education on Sustainable Development: A Micro Study in Burdwan District of West Bengal, India. American Journal of Educational Research, 4(7).

Paul, V., \& William, S. (2007). Learning for a Change: Exploring the Relationship Between Education and Sustainable Development. Journal of Education for Sustainable Development, I(2). https://doi.org/10.1177/097340820700100209

Robert, L., Yuko, N., \& Rosalyn, M. (2016). Contributions of Education for Sustain able Development (ESD) to Quality Education, A Synthesis of Research. Journal of Education for Sustainable Development, 10(2). https://doi.org/10.1177/0973408216661442

Schlottmann, A. (2010). Education and State Economic Growth: The Fundamental Linkage. White Paper, 2.

Schults, T. (2009). The Gender and General Consensus of the Demographic Transition and Population Policy: An Assessment of the Micro and Macro Linkage. Working paper No. 71, Yale University. https://doi.org/10.2139/ssrn.1488330

Scott, W., \& Gough, S. (2003). Sustainable Development and Learning: Framing the Issues. London, Routledge Flamer.

Sen, A. (1999). Development as Freedom. Oxford: Oxford University Press.

Shohel, M. M. C., \& Andrew, J. H. (2006). Non-formal Education for Sustainable Development: A Bangladeshi Perspective. The $10^{\text {th }}$ UNESCO-APEID International Conference, Bangkok, Thailand.

Sinnathurai, V. (2013). An Empirical Study on the Nexus of Poverty, GDP Growth, Dependency Ratio and Employment in Developing Countries. Journal of Competitiveness, 5(2). https://doi.org/10.7441/joc.2013.02.05

Stevens, Ph., \& Weale, M. (2004). Education and Economic Growth, in International Handbook on the Economics of Education. UKL Edward Elgar Publishing. 
Temple, J. (2002). Growth Effects of Education and Social Capital in the OECD Countries. OECD Economic Studies, 33.

Tilak, J. (2006). Trends in Public Expenditure on Education: A Contrast Between Two Educationally Backward States: Andhra Pradesh and Rajasthan. Journal of Indian School of Political Economy.

Tilak, J. B. G. (1994). Education for Development in Asia. New Delhi: Sage Publications.

Tilbury, D. (2003). Emerging Issues in Education for Sustainable Development: Education for Sustainable Development in Nepal. Views and Visions, International Institute for Global Environmental Strategies (IGES).

Tsuneki, H. (2013). Enhancing Local Disaster Risk Management Capacity in the Context of Increasing Climate-related Hazards in Cartago, Costa Rica.

UN. (1992a). Rio Declaration on Environment and Development. Presented at the United Nations Conference on Environment and Development (UNCED), Rio de Janeiro, Brazil.

UN. (1992b). Promoting Education, Public Awareness and Training of AGENDA 21. Report of the United Nations Conference on Development, Rio de Janeiro, Brazil.

UNESCO. (1997). Educating for a Sustainable Future: A Transdisciplinary Vision for Concerted Action.

UNESCO. (2002). Ubuntu Declaration on Education and Science and Technology for Sustainable Development, Paris.

UNESCO. (2006a). Framework for the DESD International Implementation Scheme. Paris: UNESCO Education Sector.

UNESCO. (2006b). Orienting Technical and Vocational Education and Training for Sustainable Development: A Discussion Paper. United Nations Decade of Education for Sustainable Development.

UNESCO. (2012a). Education for Sustainable Development Country Guidelines for Changing the Climate of Teacher Education to Address Sustainability: Putting Transformative Education into Practice. Indonesia.

UNESCO. (2012b). Shaping the Education of Tomorrow. Report on the UN Decade of Education for Sustainable Development. Paris.

UNESCO. (2012c). Exploring Sustainable Development: A Multiple-Perspective Approach. Paris.

United Nations Educational Scientific and Cultural Organization. (2005). Contributing to a More Sustainable Future: Quality Education, Life Skills, and Education for Sustainable Development.

Wals, A. J., \& Jickling, B. (2002). Sustainability in Higher Education: From Doublethink and Newspeak to Critical Thinking and Meaningful Learning. International Journal of Sustainability in Higher Education, 3(3). https://doi.org/10.1108/14676370210434688

Wedgwood, R. (2005). Education and Poverty Reduction in Tanzania, UKFIET Oxford Conference on Education and Development. University of Edinburgh.

Wolff, E., \& Gittleman, M. (1993). The Role of Education in Productivity Convergence: Does Higher Education Matter. In A. Szimai, B. van Ark, \& D. Pilat (Eds.), Explaining Economic Growth. Amsterdam: Elsevier Science Publishers.

World Commission on Environment and Development (WCED). (1987). Our Common Future. Visual Studies, 22(1).

YongJin, K., \& Terada-Hagiwara, A.(2010). A Survey on the Relationship Between Education and Growth with Implications for Developing Asia. Asian Development Bank.

\section{Copyrights}

Copyright for this article is retained by the author(s), with first publication rights granted to the journal.

This is an open-access article distributed under the terms and conditions of the Creative Commons Attribution license (http://creativecommons.org/licenses/by/4.0/). 